\title{
Comparison of Serum HIF-1a Levels in Swimming Athletes Before and After Hypoxic Non-Hypoxic Exercise
}

\author{
Syahrastani*, Argantos \\ Department of Sport Education \\ Universitas Negeri Padang \\ Padang, Indonesia \\ syahrastani.59@gmail.com
}

\author{
Dwi Hilda Putri, Dezi Handayani, Siska Alicia Farma Alisirsyah \\ Department of Biology \\ Universitas Negeri Padang \\ Padang, Indonesia \\ dwi_hildaputri@yahoo.com
}

\begin{abstract}
The situation of lack of oxygen supply to cells and tissues is often not realized by many people (hypoxia). Hypoxia can occur in various situations in life. One of them is swimming sports. The main effect of hypoxia is the effect on the brain, so the body will do everything it can to restore the state of homeostasis. HIF-1 $\alpha$ protein is a marker of hypoxic conditions that regulate the synthesis of many genes to maintain and restore body homeostasis from hypoxia to normoxia. This study was a descriptive study with a crosssectional design. The sample of this study were six swimming athletes with a 12-19 year age range who met the inclusion and exclusion criteria. The HIF-1a protein is measured by the ELISA method. Data were analyzed statistically. The results showed higher levels of HIF-1 $\alpha$ after anaerobic exercise than the levels of HIF-1 $\alpha$ before and after aerobic exercise. It is greatly influenced by the intensity of the exercise carried out. It proves that cellular adaptation to hypoxia is more stable in aerobic exercise, where the body's metabolism is more stable during aerobic exercise.
\end{abstract}

Keywords-hypoxic, HIFlalpha, aerobic, anaerobic, swimming

\section{INTRODUCTION}

Hypoxia is a condition of reduced oxygen levels at the tissue or cell level. One of the activities that often goes unnoticed under hypoxia is physical exercise. During exercise, all muscles need very large and repetitive oxygen called relative hypoxia. This is because exercise requires an intensive and sustainable energy supply.Swimming is a sport that combines aerobic and anaerobic metabolism systems. Aerobic and anaerobic training in swimmers can lead to chronic or systemic hypoxic conditions. "In swimming there are 3 types of exercise based on intensity, namely (1) Sprinter, (2) Middle Distance and (3) Distance Swimmer. Sprinters are classified as anaerobic exercises, middle distance and distance swimmers are aerobic exercises" [1]. "If observed in aquatic animals, there are some that can be an example of swimming models to observe the physiological effects of aerobic and anaerobic swimming" [1]. "These animals can survive in water for a relatively long time including the Turtle (Chelonia mydas)" [2]. Salmon (Oncorhynchus nerka), and Rainbow trout (Salmo gairdneri). "When swimming the body is at a certain depth, then the body tends to be in a state of hypoxia" [3]. This shows that there is a possibility that swimming with aerobic or anaerobic training leads to hypoxic conditions. "A has also reported that lung tissue is very responsive to oxygen deficiency conditions, this can be seen from the increased levels of HIF-1 $\alpha$ in mice that have chronic systemic hypoxia" [4]. "Lung is a very important organ in regulating breathing, especially when swimming" [5].

Protein that is involved in maintaining the body's homesotasis from hypoxic conditions is hypoxia inducible factor (HIF) which has been discovered since two decades ago by Semenza et al. The accumulation of HIF-1 $\alpha$ in hypoxic or ischemic tissue is an adaptation mechanism so that cells can survive. "Based on this background breakdown, this study was conducted to determine hypoxic conditions in aerobic and anaerobic swimming activity by comparing the levels of HIF-1 $\alpha$ protein in both activities" [6].

\section{METHODS}

This research is descriptive. Method used in this research is quantitative. Quantitative research method is a research method that based on positive philosophy and used to observe in population or certain sample. "Collecting data use research instrument, data analysis in quantitative/statistic form with the purpose is to test the hypothesis that is stated". [7]. The research was carried out in the swimming pool at the Padang State University and the Biology Laboratory of the Faculty of Mathematics and Natural Sciences, UNP.Blood samples were obtained from six junior swimming athletes with an age range of 12-19 years. Blood is collected in ependorf tubes, overnight incubation at a temperature of $4^{\circ} \mathrm{C}$ and then centrifuged at a speed of $1000 x$ g for 15 minutes at a temperature of $2-8^{\circ} \mathrm{C}$, separating the serum from the rest of the blood. Then the serum is used for measurement of total protein levels with the principle of spectrophotometry using nanodrop. Determination of HIF-1 $\alpha$ protein levels by ELISA technique using Human HIF-1 $\alpha$ (Hypoxia Inducible Factor 1 Alpha) ELISA Kit (Elabscience). The data obtained were analyzed using SPSS ver. 16 with the ANOVA test followed by the LSD test.

\section{RESULT}

Data on the weight, height and age of respondents (swimming athletes) are in Table 1. 
Table 1. Data on Body Weight, Height and Age

\begin{tabular}{|c|c|c|c|c|}
\hline No. & Code & $\begin{array}{c}\text { Body Weight } \\
(\mathrm{kg})\end{array}$ & $\begin{array}{c}\text { Height } \\
(\mathrm{cm})\end{array}$ & Age (th) \\
\hline 1 & R1 & 40 & 161 & 12 \\
\hline 2 & R2 & 77 & 184 & 19 \\
\hline 3 & R3 & 69 & 166 & 15 \\
\hline 4 & R4 & 50 & 160 & 13 \\
\hline 5 & R5 & 52 & 168 & 15 \\
\hline 6 & R6 & 51 & 163 & 16 \\
\hline
\end{tabular}

The standard curve of human HIF-1 $\alpha$ was obtained from dilution of the standard HIF-1 $\alpha$ with a concentration of 10 $\mathrm{ng} / \mathrm{mL}$ into $5 \mathrm{ng} / \mathrm{mL} ; 2.5 \mathrm{ng} / \mathrm{mL} ; 1.25 \mathrm{ng} / \mathrm{mL} ; 0.63 \mathrm{ng} / \mathrm{mL}$; $0.31 \mathrm{ng} / \mathrm{mL} ; 0.16 \mathrm{ng} / \mathrm{mL} ; 0 \mathrm{ng} / \mathrm{mL}$.

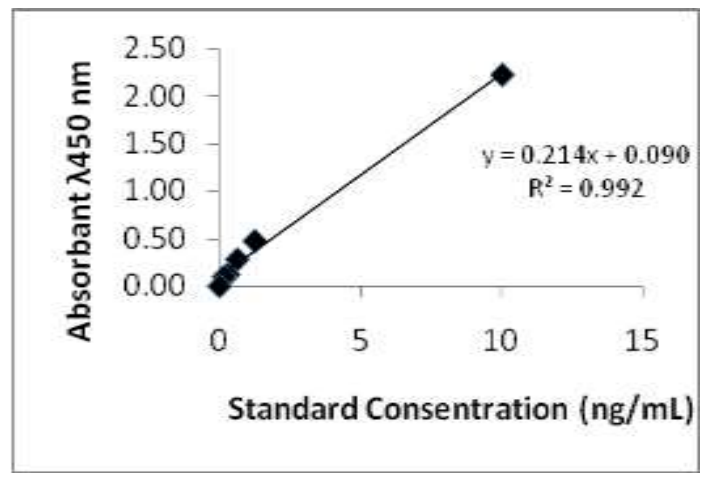

Figure 1. Standard Curve of Human HIF-1alpha

Results of serum HIF-1alevels from junior swimming athletes before and after aerobic exercice compared with anaerobic exercice.

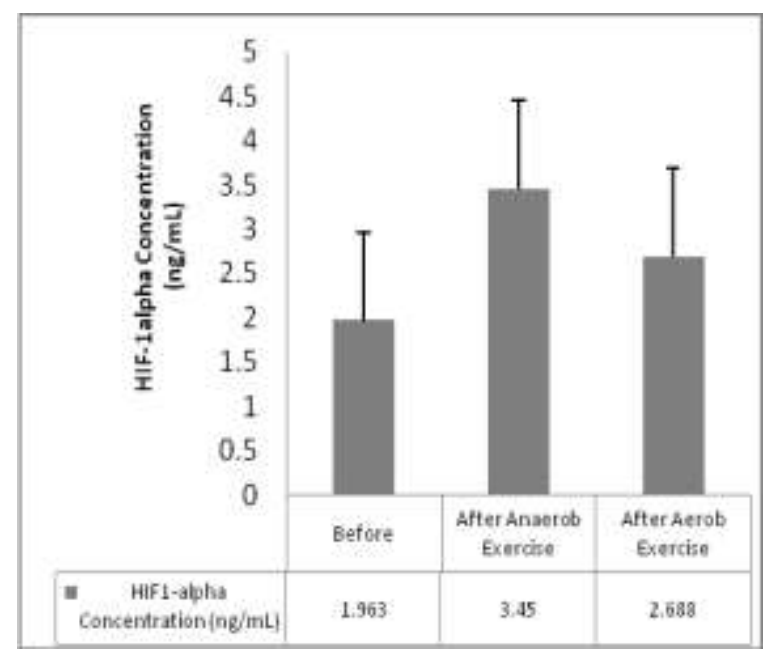

Figure 2. Human HIF-1 $\alpha$ Concentration

\section{DISCUSSION}

The condition of hypoxia is often not realized, this is due to the presence of a regulatory protein that quickly returns the body's homeostasis, HIF-1 $\alpha$. HIF- $1 \alpha$ is always expressed by most cells in both normoxic and hypoxic states, but the HIF$1 \alpha$ protein will stabilize in a hypoxic state so that its levels increase.
When the body performs physical activities such as swimming, the body responds by responding at the cellular and systemic levels.In this study measurements of HIF-1 $\alpha$ protein levels, total protein levels, blood pressure, and lung capacity of junior swimming athletes. Measurements were made before and after aerobic and anaerobic exercise. Swimming athletes who are the sample of this study have an age range of 12-19 years, with a body weight of 40-77 kg, height $160-184 \mathrm{~cm}$. The aim of the study was to compare or compare serum HIF-1 $\alpha$ levels after anaerobic and aerobic exercise.

Based on the results of the data in Figure 2 shows the high levels of serum HIF-1 $\alpha$ after anaerobic swimming compared to aerobes. This result is inversely proportional to total protein content, where total aerobic protein levels are higher than anaerobes. Anaerobic swimming conditions that prioritize speed and endurance make serum HIF-1 $\alpha$ stabilized and a number of other proteins that work under the regulation of serum HIF- $1 \alpha$ expressed. Whereas aerobic conditions showed lower serum HIF-1 $\alpha$ levels and higher total protein meant intense and prolonged swimming made the body's oxygen consumption more so that serum HIF-1 $\alpha$ proteins were not all stabilized or conditions could be said to be normoxia. While higher total protein levels in aerobic conditions indicate the possibility of the body doing a lot of metabolism in muscle protein due to long and long swimming activities.

HIF- $1 \alpha$ is a transcription factor protein that plays a role in the regulation of the expression of a number of genes. ${ }^{6,8}$ to get a picture of the mechanism of regulation of HIF-1 $\alpha$ in swimming athletes it is necessary to measure a number of genes such as lactate dehydrogenase, angiotensin converting enzyme, renin and a number of oxidative stress markers.

\section{CONCLUSION}

Based on the results of research that has been carried out, it can be concluded that HIF-1 $\alpha$ levels after anaerobic exercise are higher than HIF-1 $\alpha$ levels before and after aerobic exercise. This is strongly influenced by the intensity of the exercise carried out and proves that cellular adaptation to hypoxia is more stable in anaerobic exercise.

\section{REFERENCES}

[1] R. Ningrum, et al. "Comparison of Hemoglobins from Various Subjects Living in Hypoxia. Hayati Journal of Biosciences, vol. 20, no. 3, pp. 99-104, September. 2013

[2] Z. Peng et al. "Up-regulated HIF-1 $\alpha$ is involved in the hypoxic tolerance induced by hyperbaric oxygen preconditioning". Brain Research, vol. 12, no. 12, pp. 71-78, May 2008

[3] S. Alicia. "Respons Hif-1 $\alpha$, Anhidrase Karbonat (CA) dan Enzim Konversi Angiotensin (EKA) pada Paru Tikus (Rattus Norvegicus) yang Mengalami Hipoksia Sistemik Kronik" [Tesis]: Universitas Indonesia, 2014, pp. 56-57.

[4] E. Susanto. "Olahraga Renang sebagai Hydrotheraphy dalam Mengatasi Masalah Kesehatan". Jurnal Ilmiah Kesehatan Olahraga “MEDIKORA”FIK UNY Yogyakarta, vol. 4, no. 2, pp. 37, April. 2008

[5] Semenza. "O2-regulated gene expression: transcriptional control of cardiorespiratory physiology by HIF-1". J Appl Physiol. 2004. pp. 96.

[6] M. N. A. Setiawan. "Increasing Aerobic Durability Skill by Practicing Extensive Interval Method for Volleyball Athlete in Rokan Hulu 
Regency", Applied Science and Technology, vol. 2, no. 1, pp. 129131, February. 2018.

[7] NR. Prabhakar, GL, Semenza. "Adaptive and maladaptive cardiorespiratory responses to continuous and intermittent hypoxia mediated by hypoxia-inducible factors 1 and 2", Physiol Rev, vol, 92, no.3, pp. 967-1003, June. 2012 